\title{
栄養素センシングと神経ペプチドを介した摂食抑制
}

\author{
上田陽一
}

\section{Nutrient Sensing and Anorexia via Neuropeptides}

\author{
Yoichi Ueta \\ Department of Physiology, School of Medicine, University of Occupational and Environmental Health; \\ 1-1 Iseigaoka, Yahatanishi-ku, Kitakyushu 807-8555, Japan.
}

(Received March 3, 2017)

\begin{abstract}
Various neuropeptides play an essential role in the nutrient sensing mechanism and related homeostasis. Nesfatin-1 is a newly identified neuropeptide having anorectic activity, and nesfatin-1-containing neurons are widely distributed in the brain, including the hypothalamus and brain stem. Our previous study showed that dehydration-induced anorectic effects are mediated via the central nesfatin-1 pathway in rats. Our recent studies have also shown that peripheral anorectic peptides (cholecystokinin-8, glucagon-like peptide-1, and leptin) and an antineoplastic agent (cisplatin) caused inhibition of feeding via the central nesfatin-1 pathway in rats. Nesfatin-1-containing neurons in the central nervous system, in particular the hypothalamus and the brain stem, may mediate peripheral nutrient signals and regulate feeding behavior.
\end{abstract}

Key words——nesfatin-1; feeding; cholecystokinin-8; glucagon-like peptide-1; leptin

\section{1.はじめに}

肥満は，糖尿病，脂質異常症，高血圧，動脈硬化 などの生活習慣病の成因に深く関与した最大のリス クと考えられており，肥満をコントロールすること は生活習慣病対策のうえで重要である。 日本及び世 界中の先進国で肥満者が増加し，世界で過体重及び 肥満の人の数は, 1980 年が 8 億 8500 万人であった のに対し, 2013 年には 2.5 倍の 21 億人にまで増加 したことが報告され大きな問題となっている. ${ }^{1)}$ 増 加する肥満や生活習慣病を予防するには, その基礎 となる摂食及びエネルギー代謝調節系の解明が重要 である.

摂食行動は，消化管などの末梢臟器からの神経情 報や, 血液中のグルコース, インスリンなどの化学 的シグナルなどが脳内の特に視床下部に存在するエ ネルギー依存型摂食調節系を中心として統合され， 摂食を調節している. ${ }^{2,3)}$ この視床下部領域には多く の食欲に関係する神経ペプチドが存在し，互いに

産業医科大学医学部第 1 生理学（广807-8555 北九州市 八幡西区医生ケ丘 1-1)

e-mail: yoichi@med.uoeh-u.ac.jp

本総説は, 日本薬学会第 136 年会シンポジウムS36 で

発表した内容を中心に記述したものである.
ニューロンネットワークを形成し，栄養素センシン グとその恒常性維持に大切な役割を果たしてい

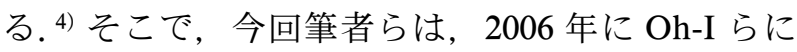
よって発見された新規の摂食抑制ペプチドである NEFA/nucleobindin 2 (NUCB2)-encoded satietyand fat-influencing protein (nesfatin-1) の脳内での 働きに注目した. ${ }^{5)} 396$ 個のアミノ酸から構成され る NUCB2 がプロホルモン変換酵素によりスプライ シングを受け, nesfatin-1, nesfatin-2, nesfatin-3 に 分かれる.このうち nesfatin-1 は $\mathrm{N}$ 末端の 82 個の アミノ酸から構成され，唯一摂食抑制作用を有して いる. ${ }^{5)} \mathrm{NUCB} 2$ のアミノ酸配列はヒト, ラット, マウスで $85 \%$ 以上の高い相同性を示す．以前，筆 者らは成熟雄性ウィスターラットに脱水負荷, 高浸 透圧負荷を行い, nesfatin-1 の発現を検討したとこ ろ, 脳弓下器官 (subfornical organ; SFO), 視索上 核 (supraoptic nucleus; SON)，室傍核（paraventricular nucleus; PVN) において nesfatin-1 ニュー ロンの活性化をみとめ, また nesfatin-1 中和抗体の 脳室内投与によって脱水誘発性摂食抑制効果が有意

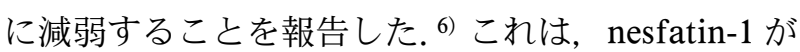
体液調節にも重要な役割を果たしていることを示唆 している。 また nesfatin-1 は摂食抑制効果だけでは 
なく，血圧やストレスなどに関する作用も報告され ており, 7,8) 摂食抑制だけではなく，代謝機能にも影 響を与える報告が散見されている.

摂食調節ペプチドには主に中枢神経に存在する摂 食六進系，摂食抑制系のペプチドのほか，主に末梢 組織に存在する摂食立進系，摂食抑制系のペプチド が報告されている，末梢に存在する摂食抑制ペプチ ドの中にコレシストキニン（cholecystokinin; $\mathrm{CCK})$ ，グルカゴン様ペプチド 1 （glucagon-like peptide-1; GLP-1), レプチンが報告されている.

末梢投与で強い摂食抑制作用を持つ CCK は主に 上部小腸の I 細胞で合成・分泌される。 ${ }^{9,10)} \mathrm{CCK}$ 分 泌臟器である消化管上部を支配する求心性迷走神経 にパラクリン様式で作用し，この神経情報をコカイ ンーアンフェタミン調節転写産物（cocaine- and amphetamine-regulated transcript; CART) を介して 延髄孤束核に伝達し，延髄孤束核のプロオペオメラ ノコルチン (proopiomelanocortin; POMC) ニュー ロンなどによって摂食を抑制する. ${ }^{11-14)} \mathrm{CCK}$ の摂食 抑制機序は，PVN や孤束核（nucleus tractus solitarius；NTS）において nesfatin-1 ニューロンを 介する可能性が先行研究で示されている. ${ }^{15-17)}$

GLP-1 は回腸の L 細胞より分泌され，インスリ ン分泌を促進し摂食抑制作用も持つペプチドであ る. ${ }^{18)}$ GLP-1 は中枢では延髄孤束核において生成さ れ，視床下部のPVNに投射しており，末梢では GLP-1 投与による摂食抑制は迷走神経求心路が関 与することが知られている。 ${ }^{19,20)}$ また孤束核 GLP-1 神経細胞は PVN に作用し, nesfatin-1 を活性化す ることも報告されているが, ${ }^{19)}$ 末梢 GLP-1 投与と nesfatin-1 の関連は不明である.

レプチンは 1994 年に発見された 146 アミノ酸残 基からなるペプチドで, 脂肪細胞に特異的に発現し ている. ${ }^{21)}$ 脂肪細胞から血中に分泌されたレプチン は，視床下部の弓状核 (arcuate nucleus; ARC) の レプチン受容体発現細胞に作用し摂食充進物質であ るニューロペプチド (neuropeptide Y; NPY)/ア グーチ関連タンパク (agouti-related protein; AgRP) ニューロン活動を抑制し，摂食抑制物質である $\mathrm{POMC} / \mathrm{CART}$ ニューロン活動を促進し，強力な捸 食抑制とエネルギー消費を促し，体重を減少させる と報告されている. ${ }^{3,22}$ 摂食行動調節にはレプチン 依存系の経路と非依存性の経路が存在することが報

告されているが, ${ }^{23)}$ レプチン受容体に異常を認める Zucker Fatty ラットにおいてもその作用発現が認め られることや，レプチンに対する抗体が nesfatin-1 による摂食抑制に拮抗しないことから， nesfatin-1 はレプチン非依存性の経路の関与が想定されてお り, 5) その関連は不明である.

このように，末梢性摂食抑制ペプチド投与による 脳内の nesfatin-1 の関連は不明な点が多い。今回筆 者らは，上記の末梢性摂食抑制ペプチド（CCK， GLP-1，レプチン）及び副作用に食思不振がある抗 腫瘍薬であるシスプラチンを腹腔内投与することに より，脳内の nesfatin-1 の活性化を明らかにし，ま た nesfatin-1 活性化による摂食抑制作用について研 究を行った.

\section{Nesfatin-1 ニューロンのラット脳内分布}

Nesfatin-1 は視床下部において，SFO，SON, PVN, ARC, 視床下部外側野 (lateral hypothalamic area； LHA）に発現し，延髄では最後野（area postrema; AP)，NTSにも発現している (Fig. 1)。 そ の他, Edinger-Westphal 核 (EW), 青斑核 (nucleus of locus coeruleus; LC), 背側縫線核 (dorsal raphe nucleus; DR), 背側運動核 (dorsal motor nucleus; DMN）にも発現が認められる. ${ }^{24,25)}$ Nesfatin-1 の各 神経核では様々なペプチドと共存することが分かつ ており，PVNでは，オキシトシンやバゾプレッシ

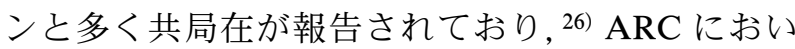
ては POMC や CART との共局在が報告されてい る. ${ }^{27)}$ 中枢では，食事などにより活性化された nesfatin-1 は樹状突起より分泌され，隣接又は共局在 するオキシトシンニューロンをオートクライン・パ ラクライン様に活性化する. 活性化されたオキシト シンは投射先の 1 つである NTS の POMCニュー ロンを活性化し，摂食抑制をひきおこすことが報告 されている. ${ }^{26-29)}$ その他, corticotropin-releasing

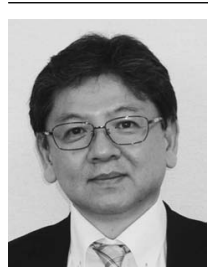

上田陽一
産業医科大学副学長・医学部第 1 生理 学教授, 医学博士. 1987 年産業医科大 学医学部卒業, 1991 年同大学院医学博 士課程修了，1993-95 年英国ブリスト ル大学研究員, 2000 年より産業医科大 学医学部第 1 生理学教授, 2017 年より 同大学副学長（教育研究担当）兼任, 現在に至る。専門は, 神経内分泌学, 一貫して視床下部-下垂体系に焦点を当 てて研究している. 
A

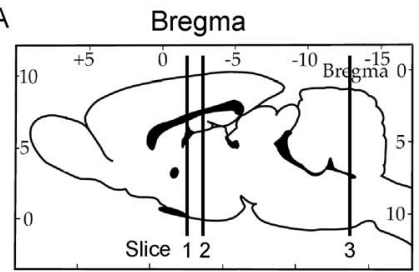

$\mathrm{B}$

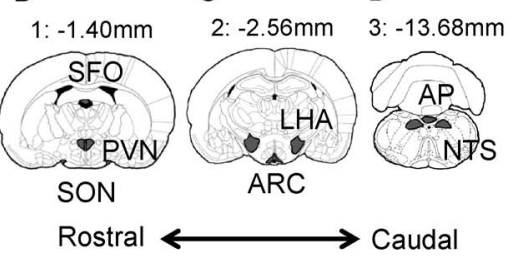

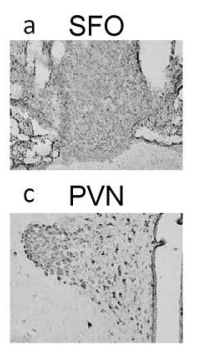

e ARC

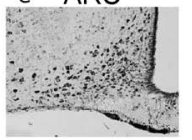

g AP

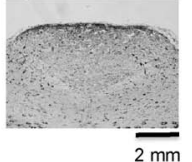

b SON

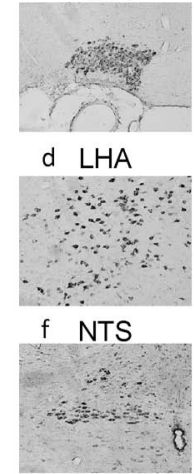

h ARC (enlarged)

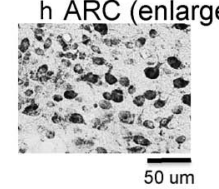

Fig. 1. Hypothalamic and Brain Stem Sections Labeled with Nesfatin-1

(A) Schematic diagrams of brain sections adapted from the rat brain atlas of Paxinos and Watson represent the approximate anteroposterior levels (to the bregma) where selected brain regions were analyzed. (B) The supraoptic nucleus (SON) and paraventricular nucleus (PVN). (C) The lateral hypothalamic area (LHA) and arcuate nucleus (ARC). (D) The area postrema (AP) and nucleus tractus solitarius (NTS). Nesfatin-1-immunoreactive cells in the hypothalamus and brain stem. (a) The subfornical organ (SFO). (b) The supraoptic nucleus (SON). (c) The paraventricular nucleus (PVN). (d) The lateral hypothalamic area (LHA). (e) The arcuate nucleus (ARC). (f) The nucleus tractus solitarius (NTS). (g) The area postrema (AP). (h) The arcuate nucleus (ARC).

hormone（CRH）が関与する経路も報告されてい る. ${ }^{17)}$

Nesfatin-1 は当初発見された中枢に加えて未梢組 織の胃の $\mathrm{X} / \mathrm{A}$ 細胞，十二指腸，膵臓，脂肪組織に も発現している. ${ }^{30-32)}$ 末梢では nesfatin-1 は迷走神 経節細胞を活性化し，NTS の POMC を活性化する ことにより摂食抑制を起こすと報告されている が, 33-35) 末梢 nesfatin-1 の生理的意義はまだ不明な 点が多い。

3. 末梢性摂食抑制ペプチド腹腔内投与後の nesfatin-1 ニューロンの活性化と摂食行動

3-1. 末梢性摂食抑制ペプチド腹腔内投与後の摂 食抑制効果筆者らは最初に, 成熟雄性ウィス ターラットを用いて未梢性摂食抑制ペプチドの摂食 抑制効果を検討した。代謝ケージを用い，各薬剂投 与 $0.5,1,2,3$ 時間後の累積摂食量を計測した. なお,

CCK は脳神経系に存在し神経伝達物質として生理 活性を持つ 8 個のアミノ酸から構成された CCK-8 を用い，GLP-1 は最終的な活性分子型として $\mathrm{N}$ 末 端側 6 個のアミノ酸が truncateした分子型の GLP-1（7-36 amide）を用いた。 また，単独では攝 食抑制を起こさない低用量の GLP-1 $(33 \mu \mathrm{g} / \mathrm{kg})$ と 同様に単独では摂食抑制を起こさない低用量のレプ チン $(300 \mu \mathrm{g} / \mathrm{kg})$ の同時投与により摂食抑制効果

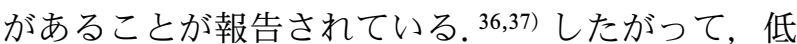
用量 GLP-1 とレプチンの同時投与と nesfatin-1 と の関連についても検討を行つた。

その結果, 高容量の GLP-1 $(100 \mu \mathrm{g} / \mathrm{kg})$ 及び CCK-8 $(50 \mu \mathrm{g} / \mathrm{kg})$ の腹腔内投与を行ったところ, 生理食塩水群と比較して有意に投与 30 分後, 1 時 間後で摂食抑制効果を認めた。また低用量の GLP-1 $(33 \mu \mathrm{g} / \mathrm{kg})$ 又は低用量のレプチン $(300 \mu \mathrm{g} /$ $\mathrm{kg}$ ）を腹腔内投与したところ，生理食塩水群と比 較して有意な摂食抑制は認めなかったが，低用量 GLP-1 と低用量レプチンを同時投与することによ り，投与 30 分， 1 時間後で有意な摂食抑制効果を 認めた。なお，低用量の GLP-1 及びレプチンの同 時投与により摂食量が低下する理由として，同時投 与により視床下部 POMC/MC4 受容体システムの 活性化及びそれに伴う AMPK の抑制が重要な分子 機構であり，また低用量 GLP-1 とレプチン同時投 与のシグナルが脳幹部の first-order neuron で統合 後，なんらかのトランスミッターにより視床下部に 伝達され，POMC/MC4 受容体システムから AMPK の抑制を介して摂食抑制を起こすと考えら れている. ${ }^{36,37)}$

3-2. 末梢性摂食抑制ペプチド腹腔内投与後の nesfatin-1 ニューロンの活性化，次に Fos タンパ 


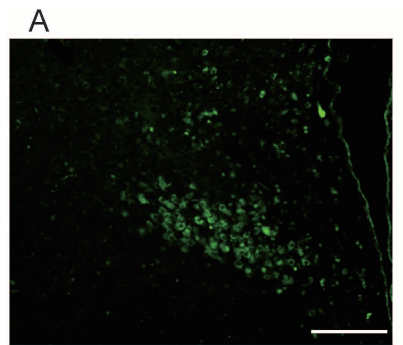

B

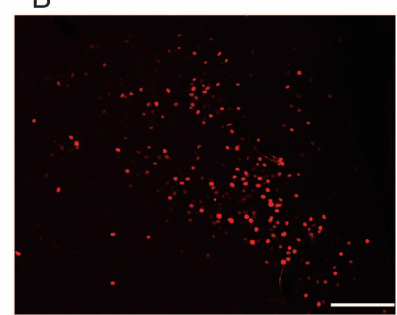

C

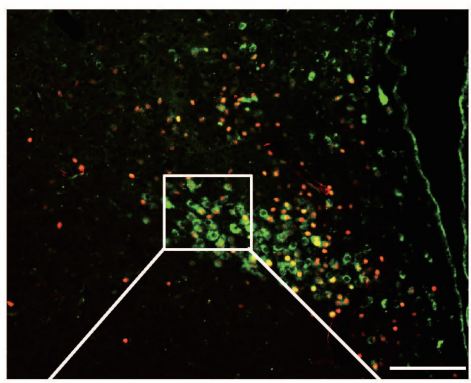

$\mathrm{D}$

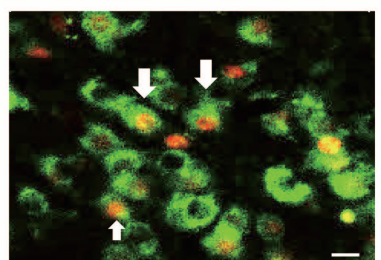

Fig. 2. Fluorescent Immunohistochemical Staining for Fos and Nesfatin-1 in the Paraventricular Nucleus (PVN) 90 min after Intraperitoneal (ip) Administration of CCK-8 $(50 \mu \mathrm{g} / \mathrm{kg})$

Photomicrographs of the PVN (A, B, and C) were obtained from the same section. Representative images of immunoreactive (ir) nesfatin-1 are shown in panel A. Representative images of Fos-ir expression are shown in panel B. Images shown in panels A and B are merged in C and D. The scale bars in low-power photomicrographs indicate $100 \mu \mathrm{m}$ and in high-power photomicrographs indicate $10 \mu \mathrm{m}$. Arrows indicate nesfatin-1-ir neurons expressing Fos-ir (D) .

クと nesfatin-1 の免疫染色を行い, nesfatin-1 ニューロンの活性化について検討した。各薬剤腹腔 内投与 90 分後に麻酔後に灌流固定を行い，脳及び 延髄を採取した。ホルマリン固定後に nesfatin-1 ニューロンが分布している SON, PVN, ARC, LHA 及び延髄の AP, NTS を含む $30 \mu \mathrm{m}$ の切片を作製し た. Fos タンパクと nesfatin-1 の蛍光二重免疫化学 的染色を行った。なお，c-fos 遺伝子は前初期遺伝 子の 1 つで, 細胞内情報伝達系の一翼を担い, ニューロンが活性化したときに一過性に Fos タン パクを産生するため, Fos タンパクは神経活動の マーカーとして汎用されている. ${ }^{38,39)}$ Fos タンパク を赤色蛍光で, nesfatin-1 を緑色蛍光で染色し, 蛍 光顕微鏡を用いて観察を行った（Fig. 2). Fos タン パク陽性細胞数, nesfatin-1 陽性細胞数, Fos と nesfatin-1 陽性細胞数をそれぞれカウントし, nesfatin-1 陽性細胞の中の Fos タンパク陽性細胞の割 合，つまり活性化している nesfatin-1 細胞の割合を 計算した。その結果, 高容量 GLP-1 投与群では,

SON $13.8 \%$, AP $24.6 \%$, NTS $12.3 \%$ のesfatin-1 ニューロンが活性化, CCK-8 投与群では SON $61.8 \%$, PVN $45.9 \%$, AP $66.7 \%$, NTS 60.0\%の nesfatin-1 ニューロンが活性化し，コントロール群と比較し有 意な上昇を認めた。ささに，低用量 GLP-1 と低用 量レプチン同時投与群でも AP 39.4\%, NTS 24.4\%
と有意な nesfatin-1 ニューロンの活性化を認めた. 摂食抑制効果を認めなかった，低用量 GLP-1 投与 群，低用量レプチン投与群ではそれぞれ各核におい て nesfatin-1 ニューロンの活性化は認めなかった.

3-3. 末梢性摂食抑制ペプチド投与後の摂食抑制 に対する効果＼cjkstart最後に， nesfatin-1 ニューロンの 活性化が摂食調節に与える影響を調べるため，nesfatin-1 のアンチセンスを用いた実験を行った。ア ンチセンスは, 高い安定性, 特異性を有するモルフォ リノアンチセンスオリゴを用い, antisense nesfatin1 (ATGGTCCTCCACCTCATCTTCAGAG), missense nesfatin-1 (ATCGTGCTCCACGTCATCTAC ACAG）を用いた. ${ }^{40)}$ Antisense nesfatin-1 若しくは missense nesfatin-1 を事前に脳室内投与し，その 後, 摂食抑制効果及び nesfatin-1 ニューロンの活性 化を認めた，高容量 GLP-1, CCK-8，低用量 GLP-1 と低用量レプチンを腹腔内投与した。 その 結果，高容量 GLP-1, CCK-8，低用量 GLP-1 と低 用量レプチン同時腹腔内投与したすべての群で, missense nesfatin-1 を脳室内投与したときには投与 30 分後，また 1 時間後に摂食抑制効果を認めたが, antisense nesfatin-1 脳室内投与した群，つまり nesfatin-1 ニューロンの活性化を阻害した群ではその 摂食抑制効果が有意に減弱する結果であった（Fig. 3). Antisense nesfatin-1 の脳室内投与により，摂 


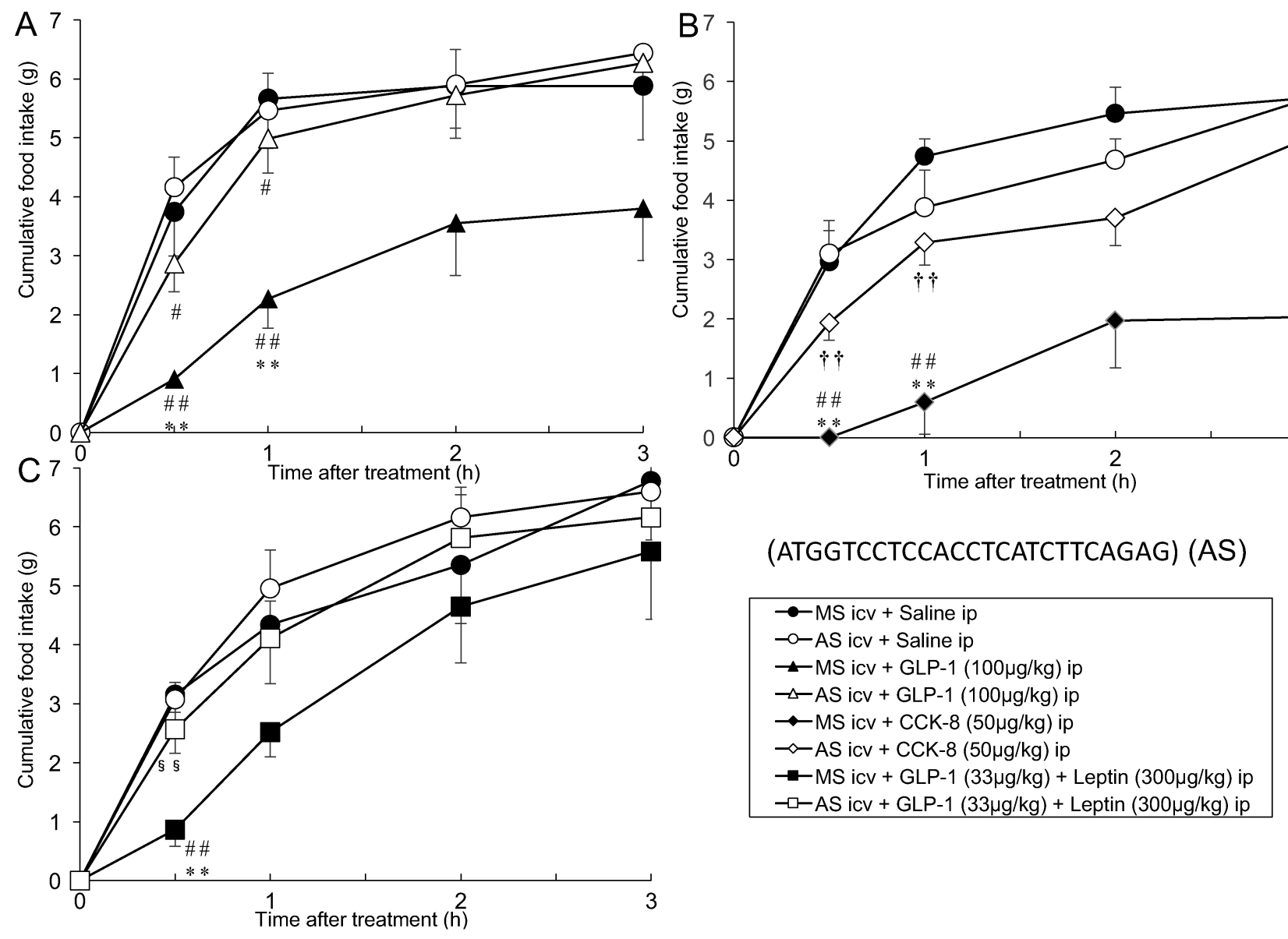

Fig. 3. Effects of Intracerebroventricular (icv) Administration of Antisense Nesfatin-1 Prior to Intraperitoneal (ip) Administration of High-dose Glucagon-like Peptide-1 (GLP-1), Cholecystokinin (CCK)-8, or a Combination of Low-dose GLP-1 and Low-dose Leptin on Food Intake

A: Effects of ip administration of saline or GLP-1 $(100 \mu \mathrm{g} / \mathrm{kg})$ and icv administration of antisense or missense nesfatin-1 on food intake in rats fasted for $24 \mathrm{~h}$ at $0,0.5,1,2$, and $3 \mathrm{~h}$ after the administration of the indicated compounds. Data are presented as mean \pm S.E.M $(n=6) .{ }^{*} p<0.01 v s$. missense nesfatin-1 icv + saline ip; ${ }^{* *} p<0.01 v s$. antisense nesfatin-1 icv + saline ip; ${ }^{*} p<0.05 v s$. missense nesfatin-1 + GLP-1 (100 $\left.\mu \mathrm{g} / \mathrm{kg}\right)$ ip. B: Effects of ip administration of saline or CCK-8 $(50 \mu \mathrm{g} / \mathrm{kg})$ and icv administration of antisense or missense nesfatin-1 on food intake in rats fasted for $24 \mathrm{~h}$ at $0,0.5,1,2$, and $3 \mathrm{~h}$ after the administration of the indicated compounds. Data are presented as mean \pm S.E.M. $(n=6) .{ }^{* *} p<0.01 v s$. missense nesfatin-1 icv + saline ip; ${ }^{* *} p<0.01 v s$. antisense nesfatin-1 icv + saline ip; ${ }^{\dagger \dagger} p<0.01 v s$. missense nesfatin-1 icv + CCK-8 $(50 \mu \mathrm{g} / \mathrm{kg})$ ip. C: Effects of ip administration of saline or a combination of GLP-1 $(33 \mu \mathrm{g} / \mathrm{kg})+\mathrm{leptin}(300 \mu \mathrm{g} / \mathrm{kg})$ and icv administration of antisense or missense nesfatin- 1 on food intake in rats fasted for $24 \mathrm{~h}$ at $0,0.5,1,2$, and $3 \mathrm{~h}$ after the administration of the indicated compounds. Data are presented as mean \pm S.E.M. $(n=6) .{ }^{*} p<0.01 v s$. missense nesfatin-1 icv + saline ip; ${ }^{* *} p<0.01$ s. antisense nesfatin-1 icv + saline ip; ${ }^{\$} s p<0.01$ $v s$. missense nesfatin-1 icv + GLP-1/leptin ip.

食抑制効果が減弱したことより，末梢性摂食抑制ぺ プチドを腹腔内投与することにより，脳内の nesfatin-1 ニューロンが活性化するが，それが摂食抑制 効果の一部を担う生理機能を持っていることが示唆 された.

以上の結果より，末梢性摂食抑制ペプチドである GLP-1, CCK-8，レプチンを末梢投与することによ り，脳室内の nesfatin-1 ニューロンが活性化し，さ らにそれが摂食抑制に係わっていることが示された (Fig. 4)。GLP-1, CCK-8 が血中に分泌され，また 治療薬として GLP-1 関連薬を投与すると, 迷走神 経求心路を介し, 延髄孤束核に働き, さらに視床下
部の SON や PVN にある nesfatin-1 ニューロンを 活性化し，㩒食抑制効果を起こす可能性，また，液 性因子を介し視床下部に直接作用し，nesfatin-1 ニューロンを活性化し摂食抑制効果を起こす可能性 が考えられる. 今回の検討では，オキシトシンや $\mathrm{CRH}$ ニューロンとの共局在は検討していないが, 以前の報告で, GLP-1 未梢投与また CCK-8 末梢投 与により, 視床下部の nesfatin-1 ニューロンとオキ シトシンや CRH ニューロンの活性化の共局在の報 告がある. ${ }^{16,17,19)}$ したがって，GLP-1 やCCK-8 末 梢投与により，視床下部の nesfatin-1 ニューロンだ けではなく, CRH やオキシトシン産生細胞を活性 


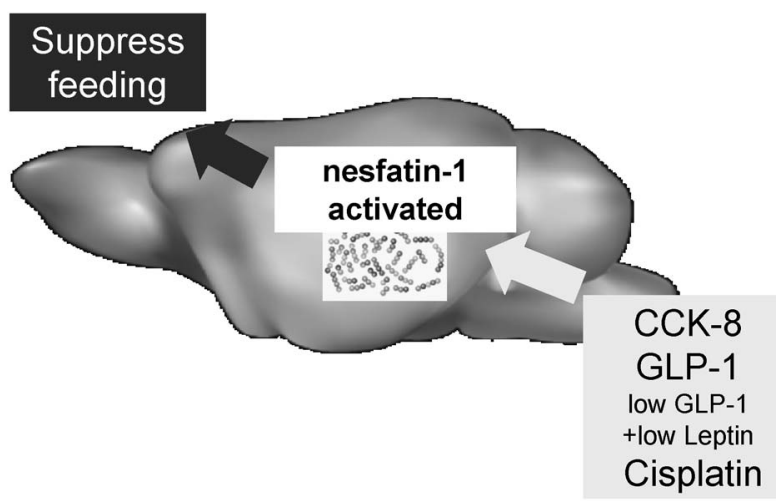

Fig. 4. Nutrient Sensing and Neuropeptides

Nesfatin-1-containing neurons are involved in inducing suppression of food intake in response to nutrient signals.

化することで摂食を抑制する可能性もある。 また, 先述したように, レプチンの摂食抑制経路は nesfatin-1 と独立していると報告されているが，今回レ プチンと同時に低用量 GLP-1 を投与したところ, nesfatin-1 ニューロンの活性化を認めた。これは, GLP-1 とレプチンを同時投与することにより，脳 幹部でそのシグナルが統合され，視床下部に伝達さ れると考えらえているが，今回，視床下部の nesfatin-1 ニューロンの活性化は認めず，延髄で活性化 が認められたため，脳幹部でのシグナル統合の際に nesfatin-1 ニューロンが関連している可能性が考え られる。

4. 抗がん剂（シスプラチン）腹腔内投与後の nesfatin-1 ニューロンの活性化と摂食行動

シスプラチンは，様々な悪性腫瘍に用いられる抗 がん剂である．化学名はシスージアンミンジクロロ 白金で，1845 年に合成され，1983 年より日本で承 認され，今では多くの腫瘍に対して使用されてい る. シスプラチンはがん細胞にある 2 つの DNA 鎖 に結合し, 強力な細胞増殖抑制効果を発揮するが, 腎障害, 聴力障害, 食思不振及び嘔吐などの強い副 作用が問題となっている。 そこで，シスプラチンに よる食思不振と脳内 nesfatin-1 の関連性を検討した.

成熟雄性ウィスターラットを用い，1）シスプラ チン $(6 \mathrm{mg} / \mathrm{kg})$ を腹腔内投与し，代謝ケージを用 い，投与 14 日後までの摂食量と体重の変化を測定, 2) シスプラチン投与 120 分後に灌流固定を行い, 脳及び延髄を採取し，Fos タンパクと nesfatin-1の 蛍光二重免疫化学的染色を行い，3） antisense nesfatin-1 を脳室内投与し, 摂食量を検討した.
その結果，1）シスプラチン投与直後より投与後 5 日目まで生理食塩水群と比較して有意に一日の摂 食量が低下し，さらに投与後 11 日目まで生理食塩 水群と比較し有意に体重増加不良を認めた。

2) Fos タンパクと nesfatin-1 の蛍光二重免疫染色 を行ったところ，視床下部の SON，PVN，ARC， LHA において，また延䯣のAP，NTS において有 意に 10-25\%程度の nesfatin-1 ニューロンの活性化 を認めた。ささらに 3) antisense nesfatin-1 及び missense nesfatin-1 を事前に脳室内投与しその後シス プラチンを腹腔内投与し，その摂食量を測定したと ころ, missense nesfatin-1 脳室内投与では投与後 $0.5,1,2,3$ 時間後まで摂食が有意に抑制されたが, antisense nesfatin-1 脳室内投与群では摂食抑制効果 が減弱し，生理食塩水腹腔内投与群とほぼ同じ量の 摂食量であった。つまり，これはシスプラチン投与 による副作用の食思不振の経路の一部に nesfatin-1 が関連していることが示唆された（Fig. 4).

\section{5. おわりに}

栄養素センシングと神経ペプチドがその恒常性維 持に果たす役割について，新規の摂食抑制ペプチド である nesfatin-1 を中心に自験例から検討を行った. 現在，シグナル伝達に関しては，PVNニューロン において nesfatin-1 が L 型カルシウムチャンネルを 介して細胞内の $\mathrm{Ca}^{2+}$ の増加や，ラット視床下部培 養細胞の nesfatin-1 による $\mathrm{Ca}^{2+}$ の増加がプロテイ ンキナーゼ A 活性化に依存することより, Gs タン パク質共役型受容体が示唆されるという報告があ る27,28)が, nesfatin-1 の受容体は同定されていない.

Nesfatin-1 の脳室内投与は，レプチン受容体変異を 持つ肥満モデル動物である Zucker Fatty Rat にお いて摂食抑制を起こし, 5) また前島らが報告した nesfatin-1 がオキシトシンニューロンを活性化し,

NTS の POMC ニューロンを活性化する経路でも正 常に働くことが報告されている. ${ }^{28)}$ したがってヒト レプチン抵抗性肥満の有効な治療薬として nesfatin-1の薬剂化が期待されている。今回明らかに なつた nesfatin-1 の脳内作用を利用した新しい治療 法開発につながる可能性もあり，今後も nesfatin-1 の脳内での役割に注目し検討していきたい.

謝辞本総説の内容は，齋藤玲子先生（産業医 科大学医学部第 1 生理学・大学院生）の研究成果を 
中心にまとめることができました，ここに深謝しま す.

利益相反＼cjkstart開示すべき利益相反はない.

\section{REFERENCES}

1) Ng M., Fleming T., Robinson M., Thomson B., Graetz N., Margono C., Mullany E. C., Biryukov S., Abbafati C., Abera S. F., Abraham J. P., Abu-Rmeileh N. M., Achoki T., AlBuhairan F. S., Alemu Z. A., Alfonso R., Ali M. K., Ali R., Guzman N. A., Ammar W., Anwari P., Banerjee A., Barquera S., Basu S., Bennett D. A., Bhutta Z., Blore J., Cabral N., Nonato I. C., Chang J. C., Chowdhury R., Courville K. J., Criqui M. H., Cundiff D. K., Dabhadkar K. C., Dandona L., Davis A., Dayama A., Dharmaratne S. D., Ding E. L., Durrani A. M., Esteghamati A., Farzadfar F., Fay D. F., Feigin V. L., Flaxman A., Forouzanfar M. H., Goto A., Green M. A., Gupta R., Hafezi-Nejad N., Hankey G. J., Harewood H. C., Havmoeller R., Hay S., Hernandez L., Husseini A., Idrisov B. T., Ikeda N., Islami F., Jahangir E., Jassal S. K., Jee S. H., Jeffreys M., Jonas J. B., Kabagambe E. K., Khalifa S. E., Kengne A. P., Khader Y. S., Khang Y. H., Kim D., Kimokoti R. W., Kinge J. M., Kokubo Y., Kosen S., Kwan G., Lai T., Leinsalu M., Li Y., Liang X., Liu S., Logroscino G., Lotufo P. A., Lu Y., Ma J., Mainoo N. K., Mensah G. A., Merriman T. R., Mokdad A. H., Moschandreas J., Naghavi M., Naheed A., Nand D., Narayan K. M., Nelson E. L., Neuhouser M. L., Nisar M. I., Ohkubo T., Oti S. O., Pedroza A., Prabhakaran D., Roy N., Sampson U., Seo H., Sepanlou S. G., Shibuya K., Shiri R., Shiue I., Singh G. M., Singh J. A., Skirbekk V., Stapelberg N. J., Sturua L., Sykes B. L., Tobias M., Tran B. X., Trasande L., Toyoshima H., van de Vijver S., Vasankari T. J., Veerman J. L., Velasquez-Melendez G., Vlassov V. V., Vollset S. E., Vos T., Wang C., Wang X., Weiderpass E., Werdecker A., Wright J. L., Yang Y. C., Yatsuya H., Yoon J., Yoon S. J., Zhao Y., Zhou M., Zhu S., Lopez A. D., Murray C. J., Gakidou E., Lancet, 384, 766-
781 (2014).

2) Lopaschuk G. D., Ussher J. R., Jaswal J. S., Pharmacol. Rev., 62, 237-264 (2010).

3) Schwartz M. W., Woods S. C., Porte D. Jr., Seeley R. J., Baskin D. G., Nature, 404, 661671 (2000).

4) Valassi E., Scacchi M., Cavagnini F., Nutr. Metab. Cardiovasc. Dis., 18, 158-168 (2008)

5) Oh-I S., Shimizu H., Satoh T., Okada S., Adachi S., Inoue K., Eguchi H., Yamamoto M., Imaki T., Hashimoto K., Tsuchiya T., Monden T., Horiguchi K., Yamada M., Mori M., Nature, 443, 709-712 (2006) .

6) Yoshimura M., Matsuura T., Ohkubo J., Maruyama T., Ishikura T., Hashimoto H., Kakuma T., Mori M., Ueta Y., Am. J. Physiol. Regul. Integr. Comp. Physiol., 307, R225R236 (2014).

7) Könczöl K., Bodnár I., Zelena D., Pintér O., Papp R. S., Palkovits M., Nagy G. M., Tóth Z. E., Neurochem. Int., 57, 189-197 (2010).

8) Yoshida N., Maejima Y., Sedbazar U., Ando A., Kurita H., Damdindorj B., Takano E., Gantulga D., Iwasaki Y., Kurashina T., Onaka T., Dezaki K., Nakata M., Mori M., Yada T., Aging, 2, 775-784 (2010).

9) Gibbs J., Young R. C., Smith G. P., Obes. Res., 5, 284-290 (1997).

10) Green G. M., Taguchi S., Friestman J., Chey W. Y., Liddle R. A., Am. J. Physiol., 256, G1016-G1021 (1989).

11) De Lartigue G., Dimaline R., Varro A., Raybould H., De la Serre C. B., Dockray G. J., Gastroenterology, 138, 1479-1490 (2010) .

12) Fan W., Ellacott K. L., Halatchev I. G., Takahashi K., Yu P., Cone R. D., Nat. Neurosci., 7, 335-336 (2004).

13) Iwasaki Y., Yada T., Neuropeptides, 46, 291297 (2012).

14) Peters J. H., Ritter R. C., Simasko S. M., Am. J. Physiol. Regul. Integr. Comp. Physiol., 290, R1544-R1549 (2006) .

15) Day H. E., McKnight A. T., Poat J. A., Hughes J., Neuropharmacology, 33, 719-727 (1994).

16) Noetzel S., Stengel A., Inhoff T., Goebel M., Wisser A. S., Bannert N., Wiedenmann B., Klapp B. F., Taché Y., Mönnikes H., Kobelt P., Regul. Pept., 157, 84-91 (2009). 
17) Stengel A., Goebel M., Wang L., Rivier J., Kobelt P., Mönnikes H., Lambrecht N. W., Taché Y., Endocrinology, 150, 4911-4919 (2009).

18) Baggio L. L., Drucker D. J., Best Pract. Res. Clin. Endocrinol. Metab., 18, 531-554 (2004).

19) Katsurada K., Maejima Y., Nakata M., Kodaira M., Suyama S., Iwasaki Y., Kario K., Yada T., Biochem. Biophys. Res. Commun., 451, 276-281 (2014).

20) Pederson R. A., White H. A., Schlenzig D., Pauly R. P., McIntosh C. H., Demuth H. U., Diabetes, 47, 1253-1258 (1998).

21) Zhang Y., Proenca R., Maffei M., Barone M., Leopold L., Friedman J. M., Nature, 372, 425-432 (1994).

22) Ebihara K., Ogawa Y., Katsuura G., Numata Y., Masuzaki H., Satoh N., Tamaki M., Yoshioka T., Hayase M., Matsuoka N., Aizawa-Abe M., Yoshimasa Y., Nakao K., Diabetes, 48, 2028-2033 (1999).

23) Shimizu H., Inoue K., Mori M., J. Endocrinol., 193, 1-9 (2007).

24) Goebel M., Stengel A., Wang L., Lambrecht N. W., Taché Y., Neurosci. Lett., 452, 241246 (2009).

25) Goebel M., Stengel A., Wang L., Taché Y., Brain Res., 1300, 114-124 (2009).

26) Kohno D., Nakata M., Maejima Y., Shimizu H., Sedbazar U., Yoshida N., Dezaki K., Onaka T., Mori M., Yada T., Endocrinology, 149, 1295-1301 (2008).

27) Brailoiu G. C., Dun S. L., Brailoiu E., Inan S., Yang J., Chang J. K., Dun N. J., Endocrinology, 148, 5088-5094 (2007).

28) Maejima Y., Sedbazar U., Suyama S., Kohno D., Onaka T., Takano E., Yoshida N., Koike M., Uchiyama Y., Fujiwara K., Yashiro T.,
Horvath T. L., Dietrich M. O., Tanaka S., Dezaki K., Oh-I S., Hashimoto K., Shimizu H., Nakata M., Mori M., Yada T., Cell Metab., 10, 355-365 (2009).

29) Yosten G. L., Samson W. K., Am. J. Physiol. Regul. Integr. Comp. Physiol., 298, R1642R1647 (2010).

30) Ramanjaneya M., Chen J., Brown J. E., Tripathi G., Hallschmid M., Patel S., Kern W., Hillhouse E. W., Lehnert H., Tan B. K., Randeva H. S., Endocrinology, 151, 31693180 (2010).

31) Stengel A., Goebel M., Yakubov I., Wang L., Witcher D., Coskun T., Taché Y., Sachs G., Lambrecht N. W., Endocrinology, 150, 232238 (2009).

32) Zhang A. Q., Li X. L., Jiang C. Y., Lin L., Shi R. H., Chen J. D., Oomura Y., World J. Gastroenterol., 16, 1735-1741 (2010) .

33) Iwasaki Y., Nakabayashi H., Kakei M., Shimizu H., Mori M., Yada T., Biochem. Biophys. Res. Commun., 390, 958-962 (2009).

34) Shimizu H., Oh-I S., Okada S., Mori M., Endocr. J., 56, 537-543 (2009).

35) Shimizu H., Ohsaki A., Oh-I S., Okada S., Mori M., Peptides, 30, 995-998 (2009).

36) Akieda-Asai S., Poleni P. E., Date Y., Am. J. Physiol. Endocrinol. Metab., 306, E1284E1291 (2014).

37) Poleni P. E., Akieda-Asai S., Koda S., Sakurai M., Bae C. R., Senba K., Cha Y. S., Furuya M., Date Y., Biochem. Biophys. Res. Commun., 420, 36-41 (2012).

38) Chaudhuri A., Neuroreport, 8, v-ix (1997).

39) Sagar S. M., Sharp F. R., Curran T., Science, 240, 1328-1331 (1988).

40) Yosten G. L., Redlinger L., Samson W. K., J. Neuroendocrinol., 24, 1078-1084 (2012). 